\title{
IAMJ
}

INTERNATIONAL

AYURVEDIC

MEDICAL JOURNAL

\section{A SURVEY STUDY ON THE ROLE OF DINCHARYA AND RITUCHARYA IN HEALTHY LIFESTYLE W.S.R. TO MAINTAIN THE BIOLOGICAL CLOCK}

\author{
Mukesh Saini ${ }^{1}$, Rajesh Kumar Sharma ${ }^{2}$, Dinesh Chandra Sharma ${ }^{3}$ \\ ${ }^{1}$ P.G. Scholar, P.G. Department of KriyaSharir, DSRRAU, Jodhpur, Rajasthan, India \\ ${ }^{2}$ Professor and H.O.D., P.G. Department of KriyaSharir, DSRRAU, Jodhpur, Rajasthan, India \\ ${ }^{3}$ Associate Professor, P.G. Department of KriyaSharir, DSRRAU, Jodhpur, Rajasthan, India
}

Corresponding Author:ㄹmukeshsaini8255@gmail.com

https://doi.org/10.46607/iamj0309092021

(Published Online: September 2021)

Open Access

(C) International Ayurvedic Medical Journal, India 2021

Article Received:11/08//2021 - Peer Reviewed:25/08/2021 - Accepted for Publication:26/08/2021

\section{Check for updates}

\begin{abstract}
Today's new world has been emerged very rapidly i.e., "lifestyle disorders". This world is concerned with chronic non-communicable diseases which have been taken the form of epidemics in the current era. Ayurveda is an absolute science of lifestyle. An ideal lifestyle has been described for health maintenance. This described lifestyle terminates all the changes which are occurred due to time. Ayurveda gives more emphasis on the prevention of diseases than treatment. Therefore, it is not only limited to the management and treatment of diseases. ${ }^{1}$ India during the epidemiological transition. The major killer diseases of the past were the plague, smallpox, cholera, trachoma, guinea worm etc. Many of the major killer diseases have been eradicated but many of them still visit the people intermittently. Tuberculosis, malaria, typhoid fever, meningitis, sexually transmitted diseases are the area of major concern at present. In a developing country like India, about 40 per cent of the deaths are still due to infectious, parasitic, respiratory diseases compared with about 8 per cent in developed countries. In addition to this due to changing lifestyle, living standards, some demographical factors, urbanization, industrialization, and widespread effects of technology etc. Non-Communicable Diseases (NCDs) has emerged as the major killer disease in the present era. It is accounting for over $60 \%$ of all deaths. According to a World Health Organization (WHO) report (2002), cardiovascular diseases (CVDs) will be the major cause of deaths and disabilities in India by 2020. NCDs cause significant morbidity and mortality both in urban and rural populations, with considerable loss in
\end{abstract}


potentially productive years (aged 35-64 years) of life. Besides the NCDs, tuberculosis like communicable diseases is a huge health burden in India at present. Most of the developed countries have controlled tuberculosis even much before the advent of BCG or chemotherapy, whereas India accounts for nearly one-fifth (20\%) of the global burden of tuberculosis at present times. There were approximately 29.8 million patients with cardiovascular disease in India during the year 2003 and an estimated 1.5 million deaths per year due to the same cause. The total numbers of stroke cases in India in the year 2004 were about 6.36 million with about 0.63 million deaths and there are approximately 2 to 2.5 million cancer patients at any given point of time, with around 7-9 lakh new cases being detected each year and around half of these cases die each year in India. ${ }^{13}$

Keywords: Ayurveda, lifestyle disorders, non-communicable diseases, tuberculosis, patients.

\section{INTRODUCTION}

The regimen which is followed in daily life and also practiced continuously day by day is called Dinacar$y a^{\prime \prime}$. The term "lifestyle' denotes the way people live'. Lifestyle factors such as personality traits, living habits, nutrition, physical exercise, use of alcohol, drug, smoking of nicotine, behavioural pattern etc. are responsible for good or bad health. A healthy lifestyle is always responsible for good health whereas an improper lifestyle is responsible for bad health or diseases. Hence, several Ayurveda classics advocated for the exercise of an ideal lifestyle (includes Dinacarya, Nishacarya, Ritucarya) and cited it as the sole disease preventive measure. Further among Dinacarya, the practice of wholesome diet and some other activities related to mental faculty help in disease prevention and health maintenance" According to the World Health Organization health has been defining as a state of complete physical, mental and social wellbeing and not merely an absence of disease or infirmity. Therefore, not only physical components, mental and social components also are equally responsible for total health. The practice of Sadvritta, as a part of Dinacarya is liable for the maintenance of social as well as mental health. ${ }^{2}$

Changes in environment and morphological description of plants are explained in Ayurvedic texts during months of various Ritus which should be observed, and one should follow Ritucharya accordingly. Nonobservance of Ritucharya leads to disequilibrium of Doshas, which comes out as various diseases. Also, the lifestyle and behavioural patterns of people are changing day by day and we are ignoring the sound of our inner soul by going away from nature. With these changes, the prevalence of diseases is also showing an upward trend in most countries. To overcome these problems, lifestyle modification in the form of the observance of Ritucharya is mandatory. In the present scenario, the increased prevalence of disorders also increasing the awareness of individuals towards the health along with the family, community and whole nation and has made people more alert for their life. Hence this is the right time to project the concept of Ritucharya in front of the general people of the world. ${ }^{8}$

Life expectancy in India is currently 66 years but is expected to climb to 73 by 2050 . According to the 2001 census, there were 75.93 million Indians above the age of sixty years and the projections for the next five censuses till the year 2051 are- 96.30 million (2011). 133.32 million (2021), 178.59 (2031), 236.01 million (2041) and 30096 million (2051). India stands to lose $\$ 4.58$ trillion before 2030 due to NCDs and mental health conditions. Data from 2004 indicates that NCDs accounted for $40 \%$ of all hospital stays and roughly $35 \%$ of all recorded outpatient visits. One estimate is that India will have lost $\$ 237$ billion in 1998 constant international dollars) between 2006 and 2015 from premature deaths due to heart disease, stroke, and diabetes 2-a a huge social and economic loss. The ailments which arise due to an unhealthy lifestyle only can be prevented through a healthy lifestyle. In ancient India, the incidence of lifestyle-related non-communicable diseases was less as the Dinacarya, Ratricarya, Ritucarya etc. (life- 
style) were incorporated in traditional life. In a country like India, where traditional lifestyles persist to some extent, the incidences of such diseases are comparatively less than so-called developed countries. $^{14}$

According to Ayurveda, disharmony of Tridoshai.e., Vata, Pitta and Kapha are the main cause of diseases and harmony causes good health. The Tridosha get elevated or diminished according to various Ritu, parts of day etc. although this variation is within normal limits. For example, Kapha Dosha is predominant in the morning, just after intake of food, after sleep etc., but this does not cause diseases as this elevation is within normal limits. Kapha Dosha annihilating activity like Dhumapana is mentioned in the classics to restrict the dosha within normal limit, otherwise, it may cause diseases at any moment. In this way, Dinacarya acts as primordial prevention and similarly Ritucarya act as primary prevention. There are rich traditions of Ayurveda in India, it is conspicuous and accepted among all social classes. It is eternal and scientific with its parameter, but it is necessary to make it realize in today's parameters. ${ }^{3}$

\section{AIM \& OBJECTIVES}

1. To study the healthy lifestyle correlated with Ayurvedic Dincharya and Ritucharya and the reference available in ayurvedic texts and maintain to the biological clock.

2. To study how to maintain the biological clock according to the Ayurvedic Dincharya and Ritucharya.

3. Study of biological clock and role and importance in prevention of lifestyle disorders and promotion of well-being.

4. Study and analysis of references regarding narrations about Dincharya and Ritucharya in the light of maintains of the biological clock.

\section{MATERIALS AND METHODS}

\section{Research Design}

Single observational study

\section{Sources of Data}

The Data was collected from the Rajasthan Ayurved University campus and the Jodhpur city, Rajasthan.

\section{METHOD OF DATA COLLECTION}

\section{Sample Size}

The sample for the present study would consist of 500 volunteers.

\section{Sampling procedure}

A total of 500 healthy volunteers were randomly selected and evaluated to participate in the role of Dincharya and Ritucharya in a healthy lifestyle survey. The selection of the samples is made by the personal interview method. Those who fulfilled the criteria only were selected for this Survey. Out of a total of 32 questions, 26 are of Dincharya and 6 of Ritucharya, any point not understood by the respondents were explained to them on the spot. These filled questionnaires were collected from all the respondents.

\section{SELECTION OF SAMPLE: -}

\section{Inclusion Criteria}

* Age group between 16 to 70 years.

* Volunteers belonging to Rajasthan Ayurved University campus and the Jodhpur city, Rajasthan.

* Irrespective of gender \& religion

\section{Exclusion Criteria}

* A person who is younger than 16 years and older than 70 years.

* A person suffering from any disease.

* A person is not willing to participate in a study.

2. Assessment Criteria: All the volunteers registered for the survey will be analysed for their demographic profile like age, sex, marital status, etc. Dates will be evaluated on the following parameters -

a. Physical Health

* Activities of daily living

* Energy and fatigue

* Mobility Pain and discomfort

b. Psychological

* Negative feelings

* Positive feeling

* Self-esteem

c. Social Relationship

* Personal relationship

* Social support 


\section{d. Environment}

* Financial resource

* Home environment

* Participation in and opportunities for recreation

\section{OBSERVATION \& RESULTS Profile of Respondents}

A total of 500 healthy volunteers were randomly selected and evaluated to participate in the role of Dincharya and Ritucharya in a healthy lifestyle survey. 300 out of 500 volunteers were randomly selected and evaluated to participate in the role of Dincharya in a healthy lifestyle survey and 200 out of 500 vol- unteers were randomly selected and evaluated to participate in the role of Ritucharya in the healthy lifestyle survey. Those who fulfilled the criteria only were selected for this Survey. Out of a total of 32 questions, 26 are of Dincharya and 6 of Ritucharya, any point not understood by the respondents were explained to them on the spot. These filled questionnaires were collected from all the respondents.

In the present study the observations were made under the following headings:

* Demographic observations

* Observations of Dincharya questionnaires

* Observations of Ritucharya questionnaires

\section{DEMOGRAPHIC OBSERVATIONS}

Table 1: Distribution according to age

\begin{tabular}{|l|l|l|l|}
\hline S. No. & Age & Frequency & Percentage $(\%)$ \\
\hline 1. & $16-20$ & 41 & 8 \\
\hline 2. & $20-30$ & 387 & 78 \\
\hline 3. & $30-40$ & 46 & 9 \\
\hline 4. & $40-55$ & 22 & 4 \\
\hline 5. & $55-70$ & 4 & 1 \\
\hline & Total & 500 & 100 \\
\hline
\end{tabular}

It is observed that in the present study, the highest percentage distribution of individuals was found in the age group $20-30$ years i.e., $78 \%, 9 \%$ in $30-40$ years, $8 \%$ in $16-20$ years, $4 \%$ in $40-55$ years and $1 \%$ in the age group between 55-70 years of participants were found males in this study.

Table 2: Distribution according to Gender

\begin{tabular}{|l|l|l|l|}
\hline S. No. & Sex & Frequency & Percentage (\%) \\
\hline $\mathbf{1 .}$ & Male & 166 & 33 \\
\hline $\mathbf{2 .}$ & Female & 334 & 67 \\
\hline & Total & $\mathbf{5 0 0}$ & $\mathbf{1 0 0}$ \\
\hline
\end{tabular}

It is observed that $67 \%$ of participants were found females and $33 \%$ of participants were found males in this study.

Table 3: Distribution according to Religion

\begin{tabular}{|l|l|l|l|}
\hline S. No. & Religion & Frequency & Percentage (\%) \\
\hline $\mathbf{1 .}$ & Hindu & 442 & 89 \\
\hline $\mathbf{2 .}$ & Muslim & 47 & 9 \\
\hline $\mathbf{3 .}$ & Christian & 2 & 0 \\
\hline $\mathbf{4 .}$ & Sikh & 9 & 2 \\
\hline & Total & $\mathbf{5 0 0}$ & $\mathbf{1 0 0}$ \\
\hline
\end{tabular}

$89 \%$ of participants were found which belongs to the Hindu religion, $9 \%$ from Muslim religion, $0 \%$ from Christian and $2 \%$ from Sikh religion. 
Table 4: Distribution according to Marital Status

\begin{tabular}{|l|l|l|l|}
\hline S. No. & Marital Status & Frequency & Percentage (\%) \\
\hline $\mathbf{1 .}$ & Married & 167 & 33 \\
\hline $\mathbf{2 .}$ & Unmarried & 333 & 67 \\
\hline & Total & $\mathbf{5 0 0}$ & $\mathbf{1 0 0}$ \\
\hline
\end{tabular}

It is observed that $67 \%$ of participants were found married and $33 \%$ of participants were found unmarried in this study.

Table 5: observations of Dincharya questionnaires

\begin{tabular}{|l|l|l|}
\hline Acharya & Follow & Not follow \\
\hline Brahma Muhurta & $33 \%$ & $67 \%$ \\
\hline Ushapan & $62 \%$ & $38 \%$ \\
\hline Shauch & $92 \%$ & $8 \%$ \\
\hline Aachmana & $73 \%$ & $27 \%$ \\
\hline Datun & $78 \%$ & $22 \%$ \\
\hline Jihva Nirlekhna & $47 \%$ & $53 \%$ \\
\hline Gandusha/ Kawal & $41 \%$ & $59 \%$ \\
\hline Snaan & $98 \%$ & $2 \%$ \\
\hline Anjan & $23 \%$ & $77 \%$ \\
\hline Nasya & $7 \%$ & $93 \%$ \\
\hline Dhumpaan & $0 \%$ & $100 \%$ \\
\hline Vyaayaam & $57 \%$ & $43 \%$ \\
\hline Abhyang & $60 \%$ & $40 \%$ \\
\hline Vstr-Dhaaran & $100 \%$ & $0 \%$ \\
\hline Ratn-Dhaaran & $0 \%$ & $100 \%$ \\
\hline Aahara & $31 \%$ & $69 \%$ \\
\hline Khadaoo-Dharna & $100 \%$ & $0 \%$ \\
\hline Taambool-Dharna & $5 \%$ & $95 \%$ \\
\hline Udvartan & $32 \%$ & $68 \%$ \\
\hline Dand-Dhaarn & $0 \%$ & $100 \%$ \\
\hline Pagadee-Dhaarn & $13 \%$ & $87 \%$ \\
\hline Kshaur-Karma & $90 \%$ & $10 \%$ \\
\hline Kanghee & $92 \%$ & $8 \%$ \\
\hline Karn-Purna & $3 \%$ & $97 \%$ \\
\hline Ratricharya & $30 \%$ & $70 \%$ \\
\hline Sadvritta & $2 \%$ & $98 \%$ \\
\hline
\end{tabular}




\section{Graph 1}

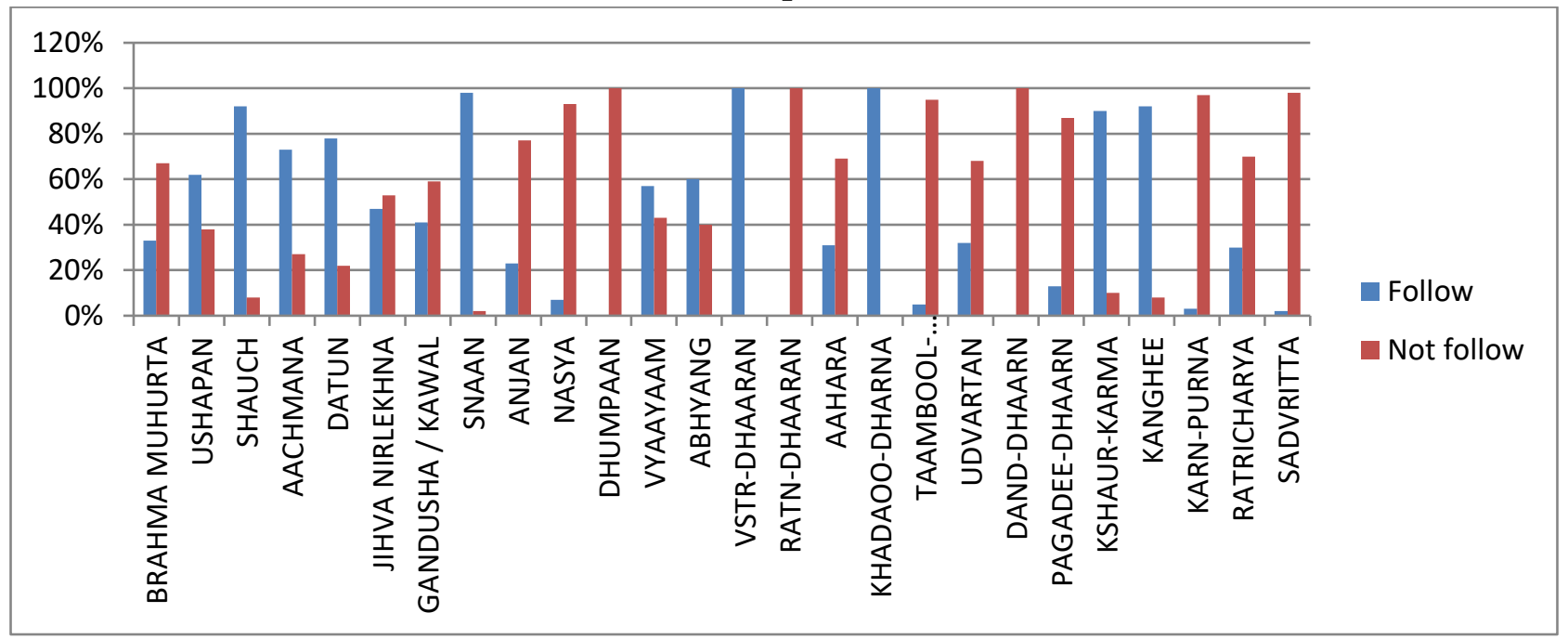

Table 6: Observations of Ritucharya questionnaires

\begin{tabular}{|l|l|l|}
\hline Ritu's & Follow & Not follow \\
\hline Sishira & $30 \%$ & $70 \%$ \\
\hline Vasanta & $23 \%$ & $77 \%$ \\
\hline Grishma & $40 \%$ & $60 \%$ \\
\hline Varsha & $17 \%$ & $83 \%$ \\
\hline Sharad & $23 \%$ & $77 \%$ \\
\hline Hemant & $40 \%$ & $60 \%$ \\
\hline
\end{tabular}

Graph 2

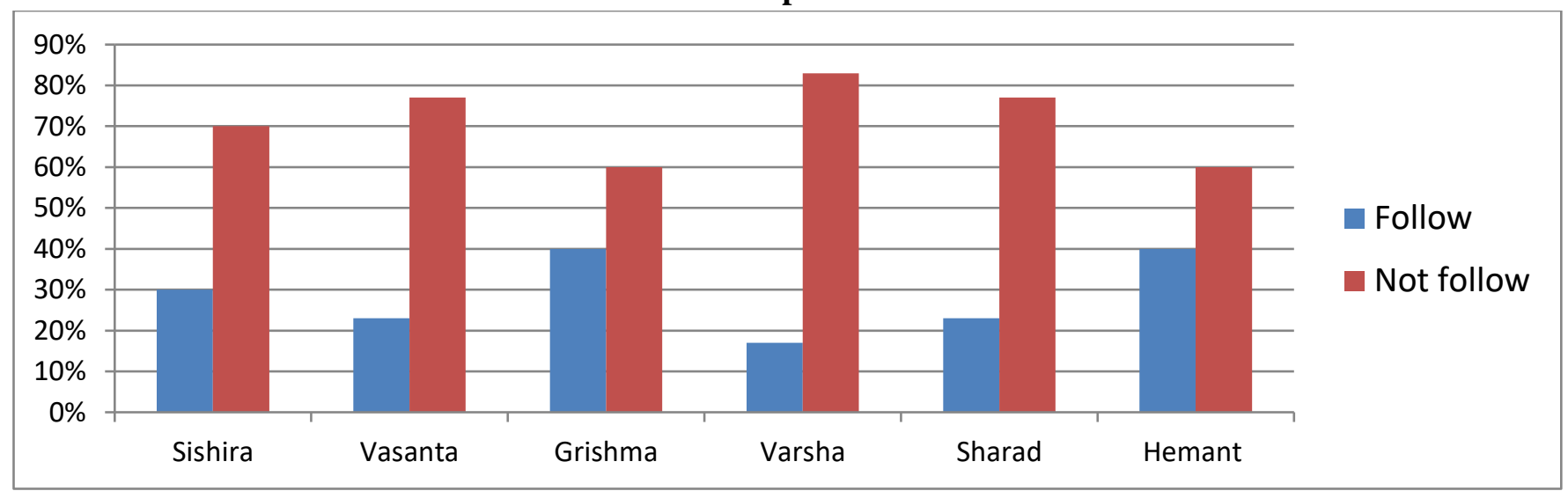

\section{DISCUSSION}

Present situation: India is going through a quick wellbeing change with an expanding weight of NonTransferable Infections (NCDs). NCDs are arising the main source of passing in India representing more than $60 \%$ of all passing. As indicated by a World
Wellbeing Association (WHO) report (2002), cardiovascular infections (CVDs) will be the significant reason for death and inability in India by 2020 NCDs cause critical dreariness and mortality both in the metropolitan and provincial populace, with extensive misfortune inconceivably profitable years (matured 35-64 years) of life. Close to the NCDs, transmittable 
sickness like tuberculosis is colossal well-being trouble in India as of now. Most of the developed nations have controlled tuberculosis even much before the approach of BCG or chemotherapy, though India represents almost one-fifth (20\%) of the worldwide weight of tuberculosis right now. There were roughly 29.8 million patients with cardiovascular illness in India during the year 2003 and assessed 1.5 million passes on each year because of the same causes. The all outnumber of stroke cases in India in the year 2004 was about 6.36 million with about 0.63 million passing 256 and there are roughly 2 to 2.5 million malignant growth patients at some random mark of time, with around 7-9 lakh new cases being distinguished every year and around half of these cases kick the bucket every year in India ${ }^{14}$.

As indicated by WHO, the principle point of wellbeing is to lead a socially and monetarily gainful life? India stands to lose $\$ 4.58$ trillion preceding 2030 due to $10 \mathrm{NCDs}$ and psychological well-being conditions. Information from 2004 demonstrates that NCDs represented $40 \%$ of all emergency clinic stays and generally $35 \%$ of all recorded outpatient visits. One gauge is that India will have lost $\$ 237$ billion (in 1998 steady worldwide dollars) somewhere in the range of 2006 and 2015 from unexpected losses because of coronary illness, stroke, and diabetes 5. Future in India is presently 66 years yet is relied upon to move to 73 by 2050359 As indicated by 2001 registration, there were 75.93 million Indians over the age of sixty years and the projections for next five censuses till the year 2051 are: 96.30 million (2011), 133.32 million (2021), 178.59 (2031), 236.01 million (2041) and 300.96 million (2051)360. The information shows that mature age populaces are the primary survivor of NCDs. The point of Ayurveda is to lead a long sound existence with no infection and personal satisfaction is the attractive objective. This is the fundamental idea of well-being as per WHO too $^{14}$.

Dinacharya implies the method of living, the eating routine and movement, which are followed for the day and step by step is called Dinacharya. It is called a way of life in the present day. The Dinacharya ref- erenced in different Ayurveda works of art are the summation of good well-being propensities and some other movement which that assists with keeping up ideal wellbeing. These exercises are answerable for prosperity not just in present life it is valuable for future life (Ubhayalokahita). Adjacent to Ayurveda works of art, some other contemporary works of art and surprisingly current allopathic content conceded that the practice of Dinacharya, which were trailed by antiquated individuals as a piece of day-by-day life was answerable for positive well-being, Through the execution of well-being related behaviors which are referenced in Veda and so forth long life can be acquired, and future may increment as long as hundred years, and inability to do so causes continually experiencing hardships, is tormented with sicknesses, and brief. Indeed, even at present, the occurrences of non-transmittable infection are less sure territory where customary life is following somewhat ${ }^{7}$. It asserts in Ayurveda that legitimate execution of Dinacharya, Ratricharya, and Ritucharya are answerable for wellbeing upkeep and sickness counteraction. Among every one of the modules of Dinacharya, Aahara (food), Vyayama (work out), Abhyanga (body back rub) and sadvritta are predominantly answerable for general actual wellbeing just as psychological wellness, though Dantadhavana (tooth brushing), Nasyakarma (nasal prescription), Anjanakarma (collyrium), Gandusha (oil pulling), Tambula Sevana (utilization of betel leaf), Dhumapana (sedated smoking), Snana (shower), Shaucavidhi (ejection of excreta and upkeep of cleanliness) are liable for appropriate capacity and support of explicit body part, which further firmly connected with general wellbeing moreover. As indicated by different examinations, there are four components identified with way of life which are fundamentally liable for the majority of the non-transferable sicknesses ${ }^{12}$.They are ill-advised eating routine, inappropriate active work, destructive utilization of liquor, and smoking. Raised weight file (overweight and corpulence) is a significant reason for ongoing non-transferable illnesses, which is mainly because of an overabundance of food utilization and less active work. The predom- 
inance of overweight is expanding step by step, information from 2005 extended that the pervasiveness of overweight in males will leap to 31 per cent in 2015 from 22 per cent and if there should arise an occurrence of female this will be $29 \%$ from $21 \%$. As per the world well-being association, in any event, $80 \%$ of untimely coronary illnesses, stroke, and type 2 diabetes and 40 per cent of diseases could be forestalled through a sound eating routine, standard active work and evasion of tobacco items. ${ }^{13}$ Every one of these preventive measures is the piece of a solid way of life. In Charakasamhita, the preventive angle, and sound way of life are referenced in Swasthacatuska and the section begins with Matrasitiyaadhyaya, further, Aaharamatra has been referenced in the under- lying piece of the part. The significance of Aahara, more explicitly Aaharamatra in the support of general well-being might be the reason behind its conversation in the underlying period of the section. Among the body part most significant has been given to Shira and named as Uttamanga in Carakasamhita. Presumably because of the significance of Shira, Anjanakarma, Dhumrapana, Nasyakarma, Dantadhavana, Gandushakarma and so on which are useful for the upkeep of strength of the design arranged above Jatru has been examined close to Aaharamatra. In the current proposition, the modules are examined in a similar request as referenced in the presentation just as in the survey parcel ${ }^{1,3}$.

Table 7

\begin{tabular}{|c|c|c|c|}
\hline Dincharya & Doshas & Merit & Demerit \\
\hline Brahmamuhurta & $\begin{array}{l}\text { Vatanuloman Kapha } \\
\text { shaman }\end{array}$ & Constipation flatulence & Aayu Agni Dhee Dhriti Smriti \\
\hline $\begin{array}{l}\text { Shauch \& Dant Dha- } \\
\text { wan \&jivha nirlekhan }\end{array}$ & Tridosh shaman & $\begin{array}{l}\text { Mukha malinta Durgandha } \\
\text { Dant roga Mukha roga Alasya } \\
\text { Angamarda }\end{array}$ & $\begin{array}{l}\text { Dant dhridta Mukh shuddhi Jivha } \\
\text { shuddhi Bhojan }\end{array}$ \\
\hline Nasya & $\begin{array}{l}\text { Kapha shaman } \\
\text { Vatanulomana }\end{array}$ & Urdhva jatrugata vikara & Eyesight Voice Glow of face \\
\hline Nasya, Gandus, Kaval & Kapha shaman & $\begin{array}{l}\text { Durganthta, Arochaka Dryness } \\
\text { of mouth Dryness of lips Dant } \\
\text { roga Mukha roga }\end{array}$ & Oral health \\
\hline Tambula sevana & Vata shaman & Hrid Roga & Mental health \\
\hline Abhyanga & Vata shaman & $\begin{array}{l}\text { Anga marda, Glani, Sandhi } \\
\text { Shool, Anidra }\end{array}$ & $\begin{array}{l}\text { Skin glow and softness SarirDadh- } \\
\text { ya,Samhanana }\end{array}$ \\
\hline Vayayama & Tridosha shaman & $\begin{array}{l}\text { Sandhi vataheart disease obesi- } \\
\text { ty }\end{array}$ & $\begin{array}{l}\text { Lightness of body Digestion Strength } \\
\text { Immunity }\end{array}$ \\
\hline Udvartana & Kapha nasak & $\begin{array}{l}\text { Obesity Compactness of body \& } \\
\text { skin }\end{array}$ & Skin compactness \\
\hline Snana & Tridosha shaman & $\begin{array}{l}\text { Skin disease Prameha Exces- } \\
\text { sive sweating Drowsiness Thirst } \\
\text { Burning }\end{array}$ & $\begin{array}{l}\text { Improve digestion Vrisya Aayushya } \\
\text { Strengthen energy Utsaha Bala Varna }\end{array}$ \\
\hline
\end{tabular}




\section{CONCLUSION}

Based on the present work, a few ends are drawn as follows, Ayurveda has been assessed on earth to satisfy two points, Kept up the health of people, Treatment of patients. Ayurveda essentially centers on the first point and accepts that counteraction is superior to fix. For this reason, different standards have been planned like Dincharya, Ritucharya, Rasayana, Ratricharya, Sadviritta, and Achara these standards can be categorised into different classes as indicated by causative elements. These causative variables are likewise categorized into three gatherings. Asatmyendriyarthsamyog, Prgyapradh, Prinama

Time as a causative factor has been considered essential as it is unavoidable. So, the time has been considered in a basic way in each idea of Ayurveda. A healthy way of life is consistently answerable for great wellbeing while the inappropriate way of life is liable for awful wellbeing or illnesses. The infirmities which emerge because of undesirable ways of life just can be forestalled through the sound way of life. Ideal actual wellbeing is fundamental to perform at the level best, yet it is the psyche that accounts for $80 \%$ of physical and social issues, so command over mind has a gigantic significance which can be acquired by appropriate execution of Sadvritta. Brahma-muhurta is the second last Muhurta before dawn (computation thinking about dawn at 6 A.M) for example 96 Minutes, for example, 4:24 AM to next 48 minutes up to 5:12 A.M is considered as Brahmamuhurta. Brahma Muhurta is considered as propitious and ideal for awakening, however, the state of absorption, and wellbeing should be thought of. This period is called Amnitabela. Panchamrita of Prakriti for example Suddhavayu, Suddhajala, Suddhabhumi, and Vipulprakash and Vipulaakash are accessible just in this period. At present in India, around $40 \%$ of the passing are because of irresistible, parasitic, respiratory illnesses and practically $60 \%$ of death are because of non-transferable infections (NCDs) Four variables identified with way of life including illadvised eating regimen, ill-advised active work, hurtful utilization of liquor and smoking are chiefly liable for a large portion of the non-transmittable sicknesses.

\section{REFERENCES}

1. Chaturvedi G, Pandey K, editor, ( $1^{\text {st }}$ Ed.) Charak Samhita of Agnivesha Vol-1, Sutrasthanam, Dasha-Mahamooliya-Adhyaya-adhyaya, Chapter 30. Varanasi ChaukhambhaVishvabhartiPrakashana, Reprint 2017, 587.

2. Shastri AD, editor, ( $1^{\text {st }}$ Ed.) Vol-1, Sushruta Samhita of Sushruta, Sutrasthanam, Varnh-Parsniyeadhyayam, Chapter 21, reprint 2017, 114.

3. Chaturvedi G, Pandey K, editor, ( $1^{\text {st }}$ Ed.) Charak Samhita of Agnivesha Vol-1, Sutrasthanam, Matrashiteeya- adhyaya, Chapter 5. Varanasi Chaukhambha Vishvabharti Prakashana, Reprint 2017, 107.

4. Prof. Rajesh Kumar Sharma \& Dr Dinesh Chandra Sharma, (1 ${ }^{\text {st }}$ Ed.) Vol-1, Sharir Kriya Vigyaan, Dosha, chapter 3, Sakshi publishing house, Jaipur, reprint 2016-17, 8, 9, 10, 27.

5. Chaturvedi G, Pandey K, editor, ( $1^{\text {st }}$ Ed.) Charak Samhita of Agnivesha Vol-1, Sutrasthanam, Matrashiteeya- adhyaya, Chapter 5. Varanasi Chaukhambha Vishvabharti Prakashana, Reprint 2017, 113-133.

6. Shastri AD, editor, ( $1^{\text {st }}$ Ed.) Vol-1, Sushruta Samhita of Sushruta, Chikitsasthanam, anaagatbaadha-prati-shedhaniya- adhyaya, Chapter 24, reprint 2017, 133-143.

7. Pro. Ravidutt Tripathi, editor, (1 ${ }^{\text {st }}$ Ed.) Vol-1, Ashtangahridayam of Srimadvagbhata, $\mathrm{Su}$ trasthanam, dinacharya-adhyayam, Chapter2, reprint 2012, 27, 42.

8. Vagbhata, in Ashtanga Sangraha, Sutra Sthana, Dinacharya-Adhyaya, and Chapter 3, 1st edition. Sharma SP, editor. Varanasi: Chaukambha Sanskrit Series Office; 2006, 55-70.

9. Chaturvedi G, Pandey K, editor, ( $1^{\text {st }}$ Ed.) Charak Samhita of Agnivesha Vol-1, Sutrasthanam, Tasyashiteeya- adhyaya, Chapter 6. Varanasi Chaukhambha Vishvabharti Prakashana, Reprint 2017, 134-149. 
10. Shastri AD, editor, (1 $1^{\text {st }}$ Ed.) Vol-1, Sushruta Samhita of Sushruta, Sutrasthanam, Ritucharyaadhyayam, Chapter 6, reprint 2017, 27-32.

11. Shastri AD, editor, ( $1^{\text {st }}$ Ed.) Vol-2, Sushruta Samhita of Sushruta, Uttara-Tantra, SvasthaVrittaadhyaya, Chapter 64, reprint 2017, 610617.

12. Pro. Ravidutt Tripathi, editor, (1 ${ }^{\text {st }}$ Ed.) Vol-1, Ashtangahridayam of Srimadvagbhata, Sutrasthanam, Ritucharya-adhyayam, Chapter3, reprint 2012, 43, 55.

13. https://www.ncbi.nlm.nih.gov/pmc/articles/PMC 6515727/

14. https://www.who.int/news-room/factsheets/detail/noncommunicable-diseases

\section{Source of Support: Nil \\ Conflict of Interest: None Declared}

How to cite this URL: Mukesh Saini et al: A Survey Study On The Role Of Dincharya And Ritucharya In Healthy Lifestyle W.S.R. To Maintain The Biological Clock. International Ayurvedic Medical Journal \{online\} 2021 \{cited September 2021\} Available from: http://www.iamj.in/posts/images/upload/1933_1942.pdf 